\title{
Inhibitory Activities of Lactic Acid Bacteria against Multi-Drug Resistant Uropathogenic Staphylococcus saprophyticus Isolated from Symptomatic Women in Lagos, Nigeria
}

\author{
Tajudeen Akanji Bamidele ${ }^{1 *}$, Felix Oluwasegun Alao's, ${ }^{2,3}$ Victorious Chisom Ekeh ${ }^{2}$, \\ Muinah Adenike Fowora ${ }^{1}$, Bolanle Alake Adeniyi ${ }^{4}$ \\ ${ }^{1}$ Molecular Biology \& Biotechnology Department, Nigerian Institute of Medical Research, Yaba-Lagos, Nigeria \\ ${ }^{2}$ Department of Biological Sciences, Bells University of Technology, Ota, Ogun State, Nigeria \\ ${ }^{3}$ Department of Microbiology, Faculty of Science, University of Lagos, Akoka, Lagos, Nigeria \\ ${ }^{4}$ Pharmaceutical Microbiology Department, Faculty of Pharmacy, University of Ibadan, Ibadan, Nigeria \\ Email: *deletaju@yahoo.co.uk, sunfelixnaija@gmail.com, ekehvictorious@gmail.com,muinahj@yahoo.com, \\ baadeniyi@yahoo.co.uk
}

How to cite this paper: Bamidele, T.A., Alao, F.O., Ekeh, V.C., Fowora, M.A. and Adeniyi, B.A. (2020) Inhibitory Activities of Lactic Acid Bacteria against Multi-Drug Resistant Uropathogenic Staphylococcus saprophyticus Isolated from Symptomatic Women in Lagos, Nigeria. Advances in Microbiology, 10, 375-382.

https://doi.org/10.4236/aim.2020.108027

Received: June 30, 2020

Accepted: August 11, 2020

Published: August 14, 2020

Copyright $\odot 2020$ by author(s) and Scientific Research Publishing Inc. This work is licensed under the Creative Commons Attribution International License (CC BY 4.0).

http://creativecommons.org/licenses/by/4.0/

\section{(c) (i) Open Access}

\begin{abstract}
The uropathogenic Staphylococcus saprophyticus is reported severally to be resistant to the drugs often used empirically for treatment of urinary tract infections (UTIs). Their ability to exhibit resistance to multiple drugs is a great deal of threat to successes recorded in the management of UTIs caused by this pathogen. Lactic acid bacteria (LAB) have been demonstrated to exhibit antimicrobial activities but studies about their prospect against multi-drug resistant $S$. saprophyticus are quite few. This study therefore investigated activities of LAB against the multi-drug resistant $S$. saprophyticus recovered from urine samples of symptomatic women. The three different species of LAB (Lactobacillus fermentum BTA 62, Lactobacillus johnsonii BTA 86 and Weissella confusa BTA 40) previously isolated and identified by $16 \mathrm{~S}$ rRNA sequencing were selected based on their history of antimicrobial activities. Their metabolites were employed in the antagonistic assays against six (6) multi-drug resistant test pathogens recovered from urine samples of symptomatic, non-pregnant women attending clinics in Lagos, Nigeria and the control $(S$. saprophyticus subs bovis strain DSM 18669) following standard procedures. The pathogens showed resistances to almost all the antibiotics except levofloxacin, ciprofloxacin, imipenem while the control showed resistance to three. The LAB, L. fermentum inhibited five (83.3\%) of the pathogens with zone diameter of $12-17 \mathrm{~mm}$, followed by $W$. confusa inhibiting three (50\%) with $15-17 \mathrm{~mm}$. Lactobacillus johnsonii on the other hand, inhibited a pathogen
\end{abstract}


and the control with zones of $13 \mathrm{~mm}$ and $14 \mathrm{~mm}$ respectively. In conclusion, the extracted metabolites of LAB inhibited the growth of multi-drug resistant clinical isolates of uropathogenic $S$. saprophyticus and may therefore be potent alternatives to antibiotics.

\section{Keywords}

Inhibitory, Lactic Acid Bacteria, Resistant, Uropathogenic, Symptomatic

\section{Introduction}

The incidence of bacterial urinary tract infection (UTI) in mostly young women, old men and rarely in children is caused by Staphylococci such as $S$. aureus, $S$. saprophyticus, and $S$. epidermidis [1] [2] [3]. Although, apart from uropathogenic Escherichia coli (UPEC) as the most common cause of UTIs, bacterial organisms such as Klebsiella pneumoniae, Enterococci spp are also implicated and thus suggests the poly-microbial nature of the infections [4] [5].

Apart from the pathogenicity of these bacteria, their resistance to antibiotics in the treatment of UTIs is demonstrated and these have given rise to recurrent episodes of the infections in $30 \%$ of young healthy women during their lifetime [6] [7] [8]. Staphylococcus saprophyticus is reputed to be second most common cause of community acquired UTIs and over $40 \%$ of all young, sexually active women have the bacterium as part of their normal genitourinary flora [9] [10] [11].

In particular, multiple drug resistance in Staphylococci which is a major and growing problem can either be hospital or community acquired while the resistance of $S$. saprophyticus to the antibiotics used commonly in the empirical treatment of uncomplicated lower UTIs in young women complicates the treatment [12].

The persistent resistance of bacterial pathogens to most of the available antibiotics has necessitated a need for harmless alternatives; therefore various approaches have been ongoing to arrest this problem. Lactic acid bacteria (LAB) with their Generally Regarded As Safe (GRAS) status have been demonstrated to exhibit antimicrobial abilities against pathogens especially the multi-drug resistant [13] [14] [15] [16] [17]. In particular, there are quite scanty data on the antagonistic abilities of LAB against multi-drug resistant uropathogenic $S$. saprophyticus despite the importance of this organism in community acquired UTIs and also its colonization in many young sexually active women. Most of the studies available reported activities against $E$. coli, Candida albicans, K. pneumoniae, Pseudomonas aeruginosa and E. faecalis [18] [19] [20] [21] which were not really multi-drug resistant.

The main thrust of this work therefore is to evaluate the in vitro antimicrobial potentials of locally isolated LAB against multi drug resistant uropathogenic $S$. saprophyticus. 


\section{Methods}

Participants and ethical consideration: The consenting non pregnant women, within age range 20 - 50 years, symptomatic for UTIs were recruited and had their urine submitted for the study. The ethical approval was obtained from the Institutional Review Board of the Nigerian Institute of Medical Research (NIMR), Yaba-Lagos, Health Research and Ethics Committee (ADM/DCST/HREC/879) of the Lagos University Teaching Hospital (LUTH), Idi-Araba, Lagos, and Health Research Ethics Committee (GBGH/705/100) of Gbagada General Hospital, Lagos, all in Nigeria.

Isolation and identification of uropathogenic $S$. saprophyticus. The urine sample was transported to the study laboratory and inoculated immediately alongside positive control S. saprophyticus subs bovis strain DSM 18669 on brain heart infusion (BHI) agar following standard microbiological/aseptic procedures.

The incubation was done in air atmosphere at $37^{\circ} \mathrm{C}$ for $48 \mathrm{~h}$ after which biochemical identification was performed according to standard guidelines. All Gram positive, coagulase negative coccal colonies that were resistant to $5 \mu \mathrm{g}$ novobiocindisc were stored in $20 \%$ glycerol-BHI at $-80^{\circ} \mathrm{C}$ until readiness for molecular identification.

The stored isolates were subcultured on BHI to confirm purity and their genomic DNA extracted using Zymo kits (Zymo Research, USA). The extracts were quantitated using qubitfluorometer and purity confirmed by Nanodrop spectrophotometric (Thermo Scientific) methods.

These were used as templates $(1 \mu \mathrm{leach})$ in PCR which was carried out using commercially sourced, $4 \mu \mathrm{l} 5 \times$ Firepol ready to load master mix (Solis BioDyne, Estonia) and $0.4 \mu \mathrm{l}$ each of $16 \mathrm{~S}$ rRNA primer pair targeting V3-V4 region(27F: 5'-AGAGTTTGATCCTGGCTCAG-3'; 1492R: 5'-GGTTACCTTGTTACGACTT-3'). The reaction was made up to $20 \mu \mathrm{l}$ with DNAse free water.

The thermal cycling parameters included initial denaturation at $95^{\circ} \mathrm{C}$ for 3 minutes followed by 30 cycles of denaturation at $95^{\circ} \mathrm{C}$ for 30 seconds, annealing at $57^{\circ} \mathrm{C}$ for 40 seconds and extension at $72^{\circ} \mathrm{C}$ for 2 minutes. The final extension took place at $72^{\circ} \mathrm{C}$ for 10 minutes before holding at $4^{\circ} \mathrm{C}$ until convenient time to remove the reaction tubes. The PCR products were resolved in $1.5 \%$ agarose gel electrophoresis at $100 \mathrm{~V}$ for $1 \mathrm{~h}$ alongside $100 \mathrm{bp}$ DNA ladder. All amplified products were sent out for sequencing.

The sequence data were subjected to Basic Local Alignment Search Tool (BLAST) algorithm in GenBank of the National Center for Biotechnology Information (NCBI) and the best hit with at least $99 \%$ similarity was taken.

Antibiotics susceptibility assay for $\boldsymbol{S}$. saprophyticus. The susceptibility assay of the pathogen to twelve (12) antibiotics was performed following the standard guidelines of Clinical and Laboratory Standards Institute (CLSI). Briefly, $0.5 \mathrm{McF}$ arland standard suspension of the pathogen $\left(10^{8} \mathrm{CFU} / \mathrm{ml}\right)$ and control (S. saprophyticus Subs bovis strain DSM 18669) was used to make lawn (using sterile swab stick) on a dried Mueller Hinton agar (MHA). The antibiotic discs were dispensed at equidistance to one another on the surface of inoculated MHA 
and incubated as per conditions for the bacterium. After incubation, the inhibition zone was measured in millimeter $(\mathrm{mm})$ and susceptibility adjudged according interpretive table.

Sources and activation of LAB: The LAB (3) used in this study were previously isolated from salad vegetables, identified with $16 \mathrm{~S}$ rRNA partial sequencing, submitted to the GenBank of NCBI and accessioned (MF 580045, MF 580058, MF 580073). They are stored at $-80^{\circ} \mathrm{C}$ at the culture bank of the Human virology and Genomics unit, NIMR.

The LAB were subcultured on de Man Rogosa Sharpe (MRS) agar, incubated in $5 \% \mathrm{CO}_{2}$ atmosphere at $37^{\circ} \mathrm{C}$ for $48 \mathrm{~h}$. All catalase, oxidase negative, Gram positive colonies were used for further assay.

LAB vs $S$. saprophyticus: This was done by agar well diffusion of cell free supernatant (CFS) from the LAB $24 \mathrm{~h}$ MRS broth culture prepared after centrifugation at 13,000 rpm for 5 minutes. One hundred (100) $\mu \mathrm{l}$ of filtered $(0.2 \mu \mathrm{m}$ Millipore) supernatant was pippeted into $8 \mathrm{~mm}$ well bored on MHA previously swabbed with $0.5 \mathrm{McF}$ arland standard $\left(10^{8} \mathrm{CFU} / \mathrm{ml}\right)$ of the pathogen and control, allowed to diffuse and incubated accordingly. After $24 \mathrm{~h}$, the plate was checked and zone of inhibition measured in $\mathrm{mm}$.

\section{Results}

Six (6) S. saprophyticus (SS1-SS6) isolated from urine samples of the women, and the control, identified with $16 \mathrm{~S}$ rRNA sequencing and exhibiting varied degrees of multiple resistances to test antibiotics were employed in the antagonistic assay. The control (S. saprophyticus subs bovis strain DSM 18669) was resistant to three (3) antibiotics while others (SS1-SS6) were resistant to at least eight (8) (Table 1).

The LAB identified as Weissella confusa BTA 40, Lactobacillus fermentum BTA 62 and Lactobacillus johnsonii BTA 86 inhibited S. saprophyticus at varied degrees. The widest inhibition $(17 \mathrm{~mm})$ was seen against SS4, SS6 by $W$. confusa and $L$. fermentum while the narrowest $(12 \mathrm{~mm})$ was against SS1 by $L$. fermentum. The CFS of L. johnsonii inhibited only SS4 and the control strain DSM 18669 (Table 2).

Table 1. Antibiotics sensitivity and resistance patterns of $S$. saprophyticus isolates.

\begin{tabular}{ccccccccccccc}
\hline & \multicolumn{10}{c}{ Antibiotics concentration $(\mu \mathrm{g}) /$ zone of inhibition $(\mathrm{mm})$} \\
\cline { 2 - 12 } Isolate & CAZ & CRX & GEN & CTR & ERY & CXC & OFL & AUG & LVS & CPR & RNF & NIP \\
& $(30)$ & $(30)$ & $(10)$ & $(30)$ & $(15)$ & $(5)$ & $(5)$ & $(30)$ & $(5)$ & $(10)$ & $(5)$ & $(10)$ \\
\hline SS1 & $\mathrm{R}$ & $\mathrm{R}$ & $\mathrm{R}$ & $\mathrm{R}$ & $\mathrm{R}$ & $\mathrm{R}$ & $\mathrm{R}$ & $\mathrm{R}$ & 30 & 26 & $\mathrm{R}$ & 26 \\
SS2 & $\mathrm{R}$ & $\mathrm{R}$ & $\mathrm{R}$ & $\mathrm{R}$ & $\mathrm{R}$ & $\mathrm{R}$ & $\mathrm{R}$ & $\mathrm{R}$ & 30 & 27 & $\mathrm{R}$ & 25 \\
SS3 & $\mathrm{R}$ & $\mathrm{R}$ & $\mathrm{R}$ & $\mathrm{R}$ & $\mathrm{R}$ & $\mathrm{R}$ & $\mathrm{R}$ & $\mathrm{R}$ & 30 & 20 & 19 & 29 \\
SS4 & $\mathrm{R}$ & $\mathrm{R}$ & $\mathrm{R}$ & $\mathrm{R}$ & $\mathrm{R}$ & $\mathrm{R}$ & $\mathrm{R}$ & $\mathrm{R}$ & 17 & 12 & $\mathrm{R}$ & 17 \\
SS5 & $\mathrm{R}$ & $\mathrm{R}$ & $\mathrm{R}$ & $\mathrm{R}$ & $\mathrm{R}$ & $\mathrm{R}$ & $\mathrm{R}$ & $\mathrm{R}$ & 30 & 29 & $\mathrm{R}$ & 28 \\
SS6 & $\mathrm{R}$ & $\mathrm{R}$ & $\mathrm{R}$ & $\mathrm{R}$ & $\mathrm{R}$ & $\mathrm{R}$ & $\mathrm{R}$ & $\mathrm{R}$ & 27 & 28 & $\mathrm{R}$ & 25 \\
$\mathrm{DSM}$ & $\mathrm{R}$ & 16 & 32 & 16 & 17 & $\mathrm{R}$ & 29 & $\mathrm{R}$ & 25 & 30 & 26 & 25 \\
\hline
\end{tabular}

Key: CAZ: Ceftazidime; CRX: Cefuroxime; GEN: Gentamicin; CTR: Ceftriaxone; ERY: Erythromycin; CXC: Cloxacillin; OFL: Ofloxacin; AUG: Augmentin; LVS: Levofloxacin; CPR: Ciprofloxacin; RNF: Cefdinir; NIP: imipenem. 
Table 2. The zone of inhibition by LAB CFS against $S$. saprophyticus.

\begin{tabular}{cccccccc}
\hline \multirow{2}{*}{ LAB (accession number) } & \multicolumn{7}{c}{ S. saprophyticus/Zone of inhibition } \\
\cline { 2 - 8 } & SS1 & SS2 & SS3 & SS4 & SS5 & SS6 & DSM \\
\hline W. confusa BTA 40 (MF 580045) & 15 & 17 & - & - & - & 17 & - \\
L. fermentum BTA 62 (MF 580058) & 12 & 17 & 14 & 15 & 13 & - & - \\
L. johnsonii BTA 86 (MF 580073) & - & - & - & 13 & - & - & 14 \\
\hline Note: - No zone of inhibition. & & & & & & &
\end{tabular}

Note: - No zone of inhibition.

\section{Discussion}

The current global problem of antimicrobial resistance (AMR) has called for spirited research into new drug in order to consolidate the successes of antibiotic era, otherwise, we will be sliding back into pre-antibiotics era. The new drug or chemotherapeutic agents should be such that will not portend side effects such as antibiotics associated diarrhoea (AAD), overgrowth of Clostridium difficile which occur as a result of overuse of antibiotics.

Lactic acid bacteria are generally regarded as safe and have proven antimicrobial activities against pathogenic microorganisms. The three selected LAB in this study have been investigated for activities against selected gastrointestinal pathogens such as outbreak strains of Vibrio cholerae O1 and Methicillin resistant Staphylococcus aureus (unpublished). The evaluation of their organic acids metabolites which exhibited potentials to inhibit the growth of Salmonella enterica Ser Typhi and vulvo-vaginal pathogenic Candida albicans has previously been demonstrated [22] [23].

The resistance profile of the test bacterium, S. saprophyticus in this study showed multiple resistance to most of the antibiotics used (Table 1), except for the quinolones, levofloxacin, ciprofloxacin and the imipenem, which showed promising in vitro inhibition. This is in contrast to the reports by [24] which demonstrated resistances of coagulase negative Staphylococci to ciprofloxacin and even the $3^{\text {rd }}$ generation cephalosporin, cefotaxime. The sensitivity of all the test pathogens in this work to imipenem followed the same pattern and this is in tandem with different reports. In our study, we recorded $>83 \%$ resistance of the pathogens tocefdinir.

Their resistance to this $3^{\text {rd }}$ generation cephalosporin was in particular, not surprising as [25] in an open label, randomized, controlled, non-inferiority clinical trial, demonstrated better activity of the drug against uropathogenic E. coli implicated in acute pyelonephritis and complicated UTI only when used in combination with other cephalosporins. It is noteworthy that the control bacterium used in this study, S. saprophyticus subs bovis strain DSM 18669 was on the other hand, sensitive to almost all the antibiotics except ceftazidime, cloxacillin to which all the test pathogens were also resistant. It can therefore be deduced that resistance of $S$. saprophyticus to these antibiotics is intrinsic and that presence of extended spectrum beta lactamase (ESBL) may be common to this bacte- 
rium. On the other hand however, their 100\% resistance to Augmentin will undermine their possession of ESBL because of beta lactamase inhibitor-clavulanic acid contained in Augmentin.

This is subject to further investigation as there seems to be paucity of research data on presence or otherwise of ESBL in S. saprophyticus.

Among the three LAB used in the antagonistic assay, L. fermentum BTA 62 showed the best spectrum of inhibition against the test pathogen (Table 2), although could not inhibit control strain, while $W$. confusa BTA 40 only inhibited 3 of the pathogens.

These 2 LAB isolated from locally grown cucumber did not show any in vitro inhibitory activities against the control strain but $L$. johnsonii BTA 86 did. This study corroborates the report of Bhola and Bhadekar 2019 about the potentials of LAB (Lactobacilli spp.) to inhibit multi-drug resistant uropathogens including Staphylococci while [26] [27] also reported probiotic LAB showing reduction in pediatric UTIs.

In our study, we could not determine the particular LAB metabolites within organic acids, bacteriocin, hydrogen peroxide et cetera responsible for inhibition of the test pathogens and also the antagonistic assay was done in vitro which may not be extrapolated for real time cellular assay.

\section{Conclusion}

The extracted metabolites of lactic acid bacteria isolated from salad vegetables exhibited in vitro inhibitory activities against multi drug resistant clinical isolates of uropathogenic S. saprophyticus.

\section{Acknowledgements}

The authors hereby appreciate the laboratory technician, Mr. Atat Ubong Prince who assisted in the storage and maintenance of our LAB isolates in the bio-freezers $\left(-80^{\circ} \mathrm{C}\right)$. We also thank the management of the Nigerian Institute of Medical Research, Yaba-Lagos, Nigeria for providing the facilities for this study.

\section{Conflicts of Interest}

The authors declare no conflicts of interest regarding the publication of this paper.

\section{References}

[1] Kaper, J.B., Nataro, J.P. and Mobley, H.T.L. (2004) Pathogenic Escherichia coli. Nature Reviews Microbiology, 2, 123-140. https://doi.org/10.1038/nrmicro818

[2] Upadhyayula, S., Kambalapalli, M. and Asmar, B.I. (2012) Staphylococcus epidermidis Urinary Tract Infection in an Infant. Case Reports in Infectious Diseases, 2012, Article ID: 983153. https://doi.org/10.1155/2012/983153

[3] Megged, O. (2014) Staphylococcus aureus Urinary Tract Infections in Children Are Associated with Urinary Tract Abnormalities and Vesico-Ureteral Reflux. Pediatric Nephrology, 29, 269-272. https://doi.org/10.1007/s00467-013-2655-9 
[4] Flores-Mireles, A.L., Walker, J.N., Caparon, M. and Hultgren, S.J. (2015) Urinary Tract Infections: Epidemiology, Mechanisms of Infection and Treatment Options. Nature Reviews Microbiology, 5, 269-284. https://doi.org/10.1038/nrmicro3432

[5] Kline, K.A. and Lewis, A.L. (2016) Gram-Positive Uropathogens, Polymicrobial Urinary Tract Infection, and the Emerging Microbiota of the Urinary Tract. Microbiology Spectrum, 4, 1-54. https://doi.org/10.1128/microbiolspec.UTI-0012-2012

[6] Ferreira, A.M., Bonesso, M.F., Mondelli, A.L., Camargo, C.H. and Cunha, M.L.R.S. (2012) Oxacillin Resistance and Antimicrobial Susceptibility Profile of Staphylococcus saprophyticus and Other Staphylococci Isolated from Patients with Urinary Tract Infection. Chemotherapy, 58, 482-491. https://doi.org/10.1159/000346529

[7] Lunacek, A., Koenig, U., Mrstik, C., Radmayr, C., Horninger, W. and Plas, E. (2014) Unexpected Multidrug Resistance of Methicillin-Resistant Staphylococcus aureus in Urine Samples: A Single-Center Study. Korean Journal of Urology, 55, 349-353. https://doi.org/10.4111/kju.2014.55.5.349

[8] Foxman, B. (2014) Urinary Tract Infection Syndromes: Occurrence, Recurrence, Bacteriology, Risk Factors, and Disease Burden. Infectious Disease Clinic of North America, 28, 1-13. https://doi.org/10.1016/j.idc.2013.09.003

[9] Natsis, N.E. and Cohen, P.R. (2018) Coagulase-Negative Staphylococcus Skin and Soft Tissue Infections. American Journal of Clinical Dermatology, 19, 671-677. https://doi.org/10.1007/s40257-018-0362-9

[10] Lala, V. and Minter, D.A. (2019) StatPearls [Internet]. StatPearls Publishing, Treasure Island.

[11] Hur, J., Lee, A., Hong, J., Jo, W.Y., Cho, O.H., Kim, S. and Bae, I.G. (2016) Staphylococcus saprophyticus Bacteremia Originating from Urinary Tract Infections: A Case Report and Literature Review. Infections and Chemotherapy, 48, 136-139. https://doi.org/10.3947/ic.2016.48.2.136

[12] Raz, R., Colodner, R. and Kunin, C.M. (2005) Who Are You-Staphylococcus saprophyticus? Clinical Infectious Diseases, 40, 896-898. https://doi.org/10.1086/428353

[13] Figueroa-Gonzalez, I., Hernandez-Sanchez, H., Rodriguez-Serrano, G., Gomez-Ruiz, L., Garcia-Garibay, M. and Cruz-Guerrero, A. (2010) Antimicrobial Effect of Lactobacillus casei Strain Shirota Co-Cultivated with Escherichia coli UAM0403. Revista Mexicana de Ingenieria Quimica, 10, 179-188.

[14] Aminnezhad, S., Kermanshahi, R.K. and Ranjbar, R. (2015) Evaluation of Synergistic Interactions between Cell-Free Supernatant of Lactobacillus Strains and Amikacin and Genetamicin against Pseudomonas aeruginosa. Jundishapur Journal of Microbiology, 8, e16592. https://doi.org/10.5812/jim.8(4)2015.16592

[15] Eggers, S., Barker, A.K., Valentine, S., Hess, T., Duster, M. and Safdar, N. (2018) Effect of Lactobacillus rhamnosus HN001 on Carriage of Staphylococcus aureus. Results of the Impact of Probiotics for Reducing Infections in Veterans (IMPROVE) Study. BMC Infectious Diseases, 18, Article No. 129. https://doi.org/10.1186/s12879-018-3028-6

[16] Allen, H.K. (2017) Alternatives to Antibiotics: Why and How. NAM Perspectives, Discussion Paper, National Academy of Medicine, Washington DC. https://doi.org/10.31478/201707g

[17] Allen, H., Trachsel, J., Looft, T. and Casey, T. (2014) Finding Alternatives to Antibiotics. Annals of New York Academy of Sciences, 1323, 91-100. https://doi.org/10.1111/nyas.12468 
[18] Manzoor, A., Ul-Haq, I., Baig, S., Qazi, J.I. and Seratlic, S. (2016) Efficacy of Locally Isolated Lactic Acid Bacteria against Antibiotic Resistant Uropathogens. Jundishapur Journal of Microbiology, 9, e18952. https://doi.org/10.5812/jim.18952

[19] Liu, Y.H., Ho, C.H., Huang, C.C. and Tsai, C.C. (2016) Inhibitory Effect of Lactic Acid Bacteria on Uropathogenic Escherichia coli-Induced Urinary Tract Infections. Journal of Probiotics and Health, 4, 144-150.

[20] Atassi, F., Pho Viet Ahn, D.L. and Lievin-Le Moal, V. (2019) Diverse Expression of Antimicrobial Activities against Bacterial Vaginosis and Urinary Tract Infections Pathogens by Cervicovaginal Microbiota Strains of Lactobacillus gasseri and Lactobacillus crispatus. Frontiers in Microbiology, 10, 2900. https://doi.org/10.3389/fmicb.2019.02900

[21] Tsai, C.C., Lai, T.M., Lin, P.P. and Hsieh, Y.M. (2018) Evaluation of Lactic Acid Bacteria Isolated from Fermented Plant Products for Antagonistic Activity against Urinary Tract Pathogen Staphylococcus saprophyticus. Probiotics and Antimicrobial Proteins, 10, 210-217. https://doi.org/10.1007/s12602-017-9302-x

[22] Bamidele, T.A., Adeniyi, B.A. and Smith, S.I. (2019) In Vitro, Acidic, Non-Proteinaceous Antifungal Activities of Lactic Acid Bacteria Isolated from Salad Vegetables against Human Pathogenic Candida albicans. African Journal of Clinical and Experimental Microbiology, 20, 137-142. https://doi.org/10.4314/ajcem.v20i2.7

[23] Bamidele, T.A. and Adeniyi, B.A. (2016) Evaluation of Organic Acids, Anti-Salmonella Activities of Lactic Acid Bacteria Isolated from Nigerian Grown Salad Vegetables. British Biotechnology Journal, 11, 1-10. https://doi.org/10.9734/BBJ/2016/22551

[24] Bhola, J. and Bhadekar, R. (2019) In Vitro Synergistic Activity of Lactic Acid Bacteria against Multi-Drug Resistant Staphylococci. BMC Complementary and Alternative Medicine, 19, 70. https://doi.org/10.1186/s12906-019-2470-3

[25] Lojanapiwat, B., Nimitvilai, S., Bamroongya, M., Jirajariyavej, S., Tiradechavat, C., Malithong, A., Predanon, C., Tanphaichitra, D. and Lertsupphakul, B. (2019) Oral Sitafloxacin vs Intravenous Ceftriaxone Followed by Oral Cefdinir for Acute Pyelonephritis and Complicated Urinary Tract Infection: A Randomized Controlled Trial. Infection and Drug Resistance, 12, 173-181. https://doi.org/10.2147/IDR.S178183

[26] Lee, S.J., Shim, Y.H., Cho, S.J. and Lee, J.W. (2007) Probiotics Prophylaxis in Children with Persistent Primary Vesicoureteral Reflux. Pediatric Nephrology, 22, 1315-1320. https://doi.org/10.1007/s00467-007-0507-1

[27] Marild, S., Hansson, S., Jodal, U., Oden, A. and Svedberg, K. (2007) Protective Effect of Breastfeeding against Urinary Tract Infection. Acta Paediatrica, 92, 164-167. https://doi.org/10.1111/j.1651-2227.2004.tb00699.x 